\title{
Computed Tomography of the Sternum and Its Articulations
}

\author{
Malcolm K. Hatfield, M.D., Barry H. Gross, M.D., Gary M. Glazer, M.D., and William Martel, M.D. \\ Department of Radiology, University of Michigan Medical Center, Ann Arbor, Michigan, USA
}

\begin{abstract}
The chest wall presents diagnostic difficulties for both the clinician and the radiologist. Because of normal variations in anatomy and ossification, analysis of the sternal region can be particularly confusing. We reviewed the normal computed tomographic (CT) appearance of the sternum in 354 patients. Important normal sternal variants included cortical unsharpness along the posterior aspect of the manubrium, lateral surfaces of the body, and at the sternal fibrocartilaginous articulations; soft tissue prominence at the junction of the sternum and costochondral cartilage; and bony sclerosis at the transitions from manubrium to body and from body to xiphoid. In seven patients with clinically significant sternal abnormality, key CT features were abnormal soft tissue mass (7/7), destruction or irregularity of the cortical contour (7/7), and abnormal increased attenuation of bone $(1 / 7)$. CT should be the radiologic study of choice in patients with suspected abnormality of the sternum and its articulations.
\end{abstract}

Key words: Computed tomography, indications Sternum - Thorax, computed tomography

Evaluation of the chest wall presents diagnostic difficulties for both clinician and radiologist. Small abnormalities may be easily missed and normal variants may simulate disease. Although computed tomography (CT) is used as a primary examination for suspected chest wall disease $[1,4]$, there is a paucity of data on CT of the sternum and its articulations $[2,3,6,8]$. Because of normal variations

Address reprint requests to: Barry H. Gross, M.D., Department of Radiology, Box 13, University of Michigan Medical Center, Ann Arbor, MI 48109, USA
Table 1. Normal sternal measurements ${ }^{\text {a.b }}$

\begin{tabular}{|c|c|c|c|c|c|c|}
\hline & $N$ & $\begin{array}{l}\text { Over- } \\
\text { all } \\
\text { mean }\end{array}$ & $\begin{array}{l}\text { Male } \\
\text { mean }\end{array}$ & $\begin{array}{l}\mathrm{Fe}- \\
\text { male } \\
\text { mean }\end{array}$ & $\begin{array}{l}\text { Mini- } \\
\text { mum }\end{array}$ & $\begin{array}{l}\text { Maxi- } \\
\text { mum }\end{array}$ \\
\hline \multicolumn{7}{|l|}{ Sternal size } \\
\hline Anteroposterior & 354 & 21.0 & 21.8 & 19.8 & 5 & 38 \\
\hline Transverse & 354 & 59.0 & 62.0 & 55.1 & 8 & 120 \\
\hline Cephalocaudal & 354 & 159.0 & 166.0 & 149.0 & 40 & 230 \\
\hline \multicolumn{7}{|l|}{ Cortical thickness } \\
\hline Manubrium & 311 & 9.5 & 9.7 & 9.1 & 4 & 21 \\
\hline Body & 306 & 6.1 & 6.6 & 5.6 & 2 & 13 \\
\hline $\begin{array}{l}\text { Sternoclavicular } \\
\text { joint distance }\end{array}$ & 335 & 6.4 & 6.9 & 5.8 & 1 & 14 \\
\hline
\end{tabular}

a All measurements in mm

b Measurements obtained at soft tissue windows (level $30 \mathrm{HU}$, window $500 \mathrm{HU}$ )

in anatomy and ossification, particularly as a function of age, CT analysis of the sternal region can be confusing. In this report we review the normal CT appearance of the sternum in 354 patients; in addition, the findings in 10 patients with sternal abnormality detected by CT are presented.

\section{Materials and Methods}

Chest CT scans of 354 patients whose ages ranged from 9 days to 94 years were retrospectively reviewed. Patients were examined for a variety of medical indications, but none had clinical or radiographic evidence of chest wall abnormality. All scans were performed on a General Electric $8800 \mathrm{CT} / \mathrm{T}$ scanner using contiguous $1 \mathrm{~cm}$ thick slices. Scans in these patients without suspected chest wall pathology were generally reviewed at soft tissue settings (window level $30 \mathrm{HU}$, window width $500 \mathrm{HU}$ ), although bone settings (window level $250 \mathrm{HU}$, window width $1000 \mathrm{HU}$ ) were used in the 10 patients who had them available. To assess normal sternal morphology the following parameters were recorded for each patient: sternal size (anteroposterior, transverse, and cephalocaudad), cortical thickness, visibility of 


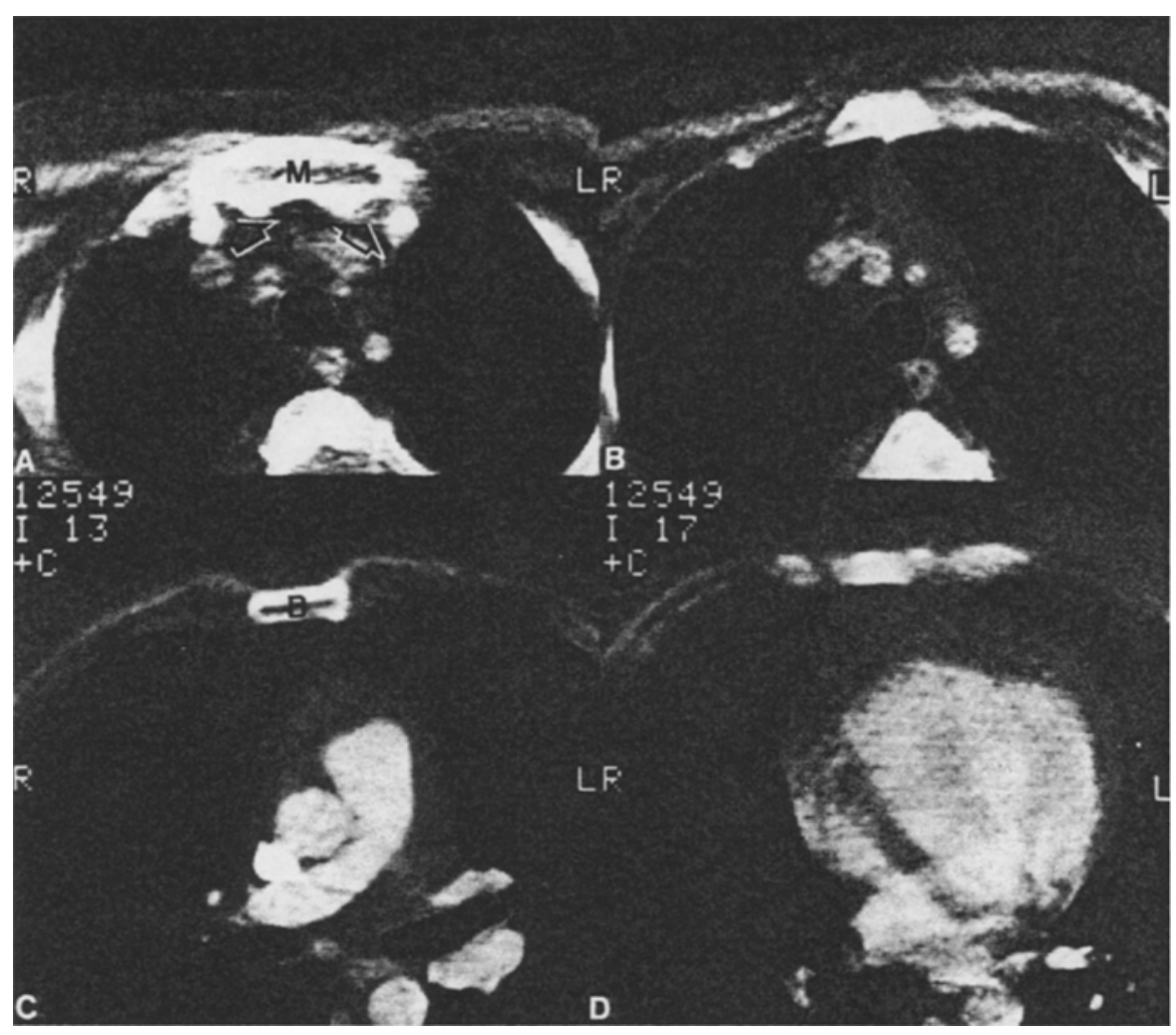

Fig. 1 A-D. Normal sternal CT A At level of sternoclavicular joints (arrows) manubrium (M) is identified

B There is increased attenuation of subarticular bone at transition from manubrium to body

$C$ Typical configuration of sternal body (B)

D Increased attenuation of bone and slight cortical irregularity identify transition from body to xiphoid

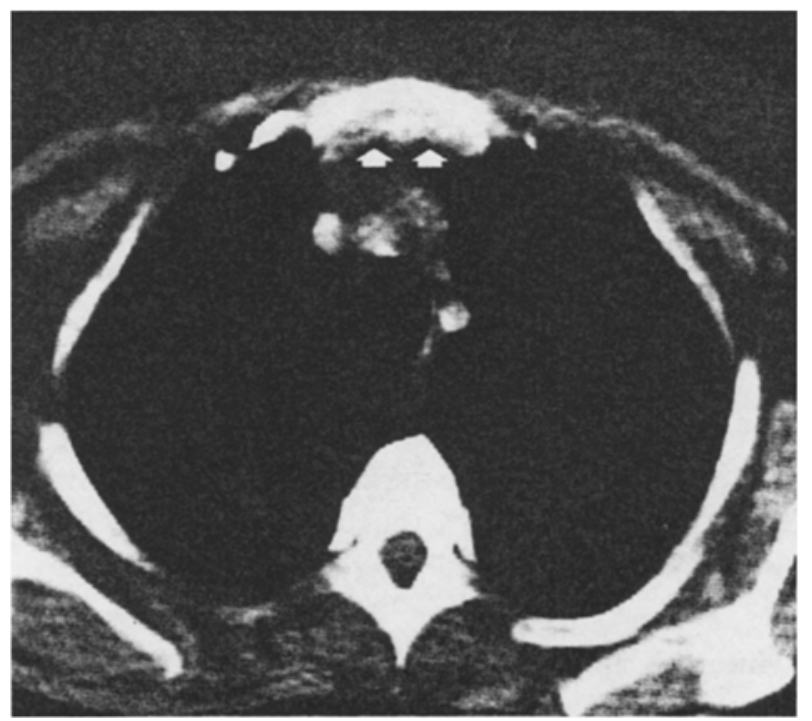

Fig. 2. Cortical unsharpness of the posterior manubrium (arrows) as a normal variant. Note absence of soft tissue mass

manubrium, body, and xiphoid, sharpness of sternal contours, sternoclavicular joint space size, sternoclavicular joint gas or bony overgrowth, and density and extent of costochondral calcification. The latter was evaluated on a scale of 0 (soft tissue density, minimal extent) to 4 (calcific density, extensive calcification). The presence or absence of calcification of the costal cartilage of the first rib was recorded for the last 260 patients in the study. In addition, the medical records of 34 patients

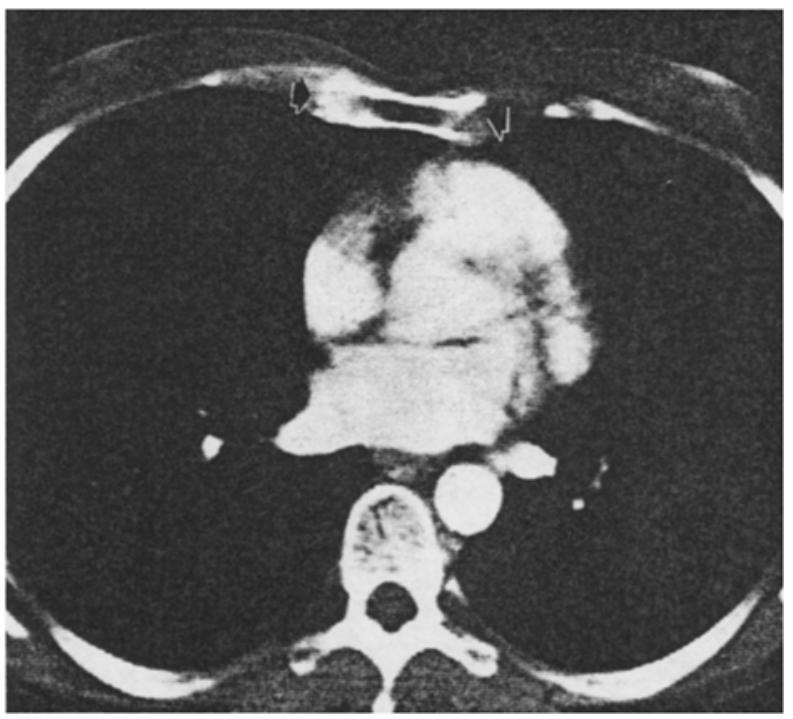

Fig. 3. Cortical unsharpness along lateral aspects of the sternal body (arrows) probably represents articulations for costal cartilage

were randomly selected to obtain data on patient height (32/34) and weight (34/34). All data underwent statistical analysis, with $P<0.05$ considered significant.

Retrospective review of all chest CT scans performed at the University of Michigan Medical Center disclosed 10 patients with clinical or radiographic evidence of sternal abnormality. For each patient, a final diagnosis was obtained from appropriate clinical, surgical, and pathologic records. 
Table 2. Costochondral calcification

\begin{tabular}{|c|c|c|c|c|c|c|}
\hline \multirow[t]{2}{*}{ Grade } & \multicolumn{3}{|l|}{ Density $^{a}$} & \multicolumn{3}{|l|}{ Extent $^{b}$} \\
\hline & Overall & Female & Male & Overall & Female & Male \\
\hline 0 & $121 / 354(34.2 \%)$ & $61 / 155(39.4 \%)$ & $60 / 199(30.2 \%)$ & $121 / 354(34.2 \%)$ & $61 / 155(39.4 \%)$ & $60 / 199(30.2 \%)$ \\
\hline 1 & $59 / 354(16.7 \%)$ & $32 / 155(20.6 \%)$ & $27 / 199(13.6 \%)$ & $139 / 354(39.3 \%)$ & $68 / 155(43.9 \%)$ & $71 / 199(35.7 \%)$ \\
\hline 2 & $50 / 354(14.1 \%)$ & $30 / 155(19.4 \%)$ & $20 / 199(10.1 \%)$ & $61 / 354(17.2 \%)$ & $21 / 155(13.5 \%)$ & $40 / 199(20.1 \%)$ \\
\hline 3 & $62 / 354(17.5 \%)$ & $18 / 155(11.6 \%)$ & $44 / 199(22.1 \%)$ & $30 / 354(8.5 \%)$ & $5 / 155(3.2 \%)$ & $25 / 199(12.6 \%)$ \\
\hline 4 & $62 / 354(17.5 \%)$ & $14 / 155(9.0 \%)$ & $48 / 199(24.1 \%)$ & $3 / 354(0.8 \%)$ & $0 / 155(0 \%)$ & $3 / 199(1.5 \%)$ \\
\hline
\end{tabular}

a Grade $0=$ soft tissue density, Grade $4=$ calcific density

b Grade $0=$ minimal extent, Grade $4=$ extensive calcification

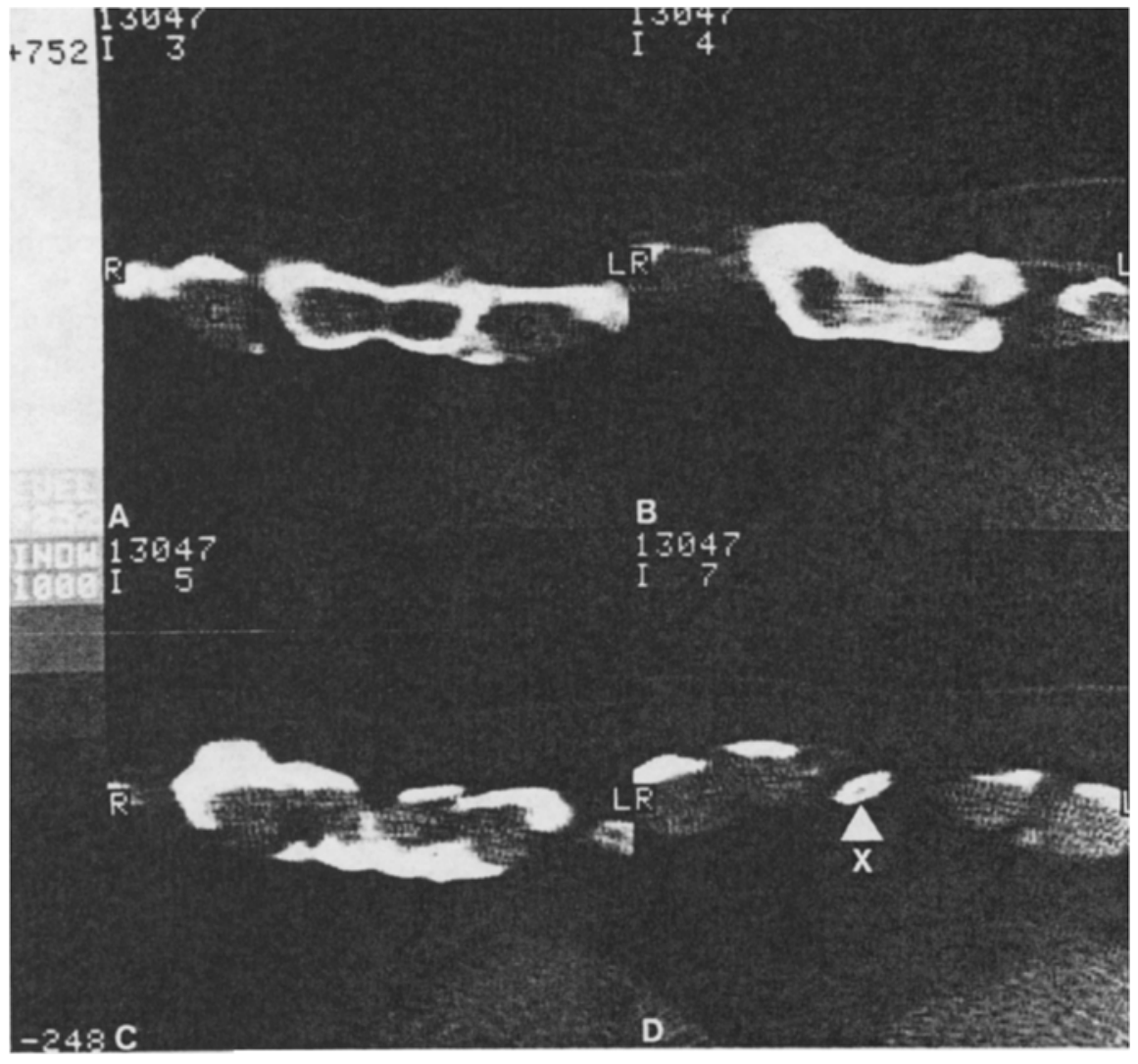

Fig. 4A-D. Case 1. Prominent soft tissues at junction of sternum and costochondral cartilage clinically simulated sternal mass

A Scan through sternal body demonstrates prominent but bilaterally symmetric costochondral junctions (C)

B There is sclerois of the sternum, but the subarticular location identifies this as a normal variant C There is marked cortical irregularity and sternal enlargement, but this is a normal finding at the transition from body to xiphoid

D Normal xiphoid (X)

\section{Results}

\section{Normal Sternums}

The study population exhibited a bimodal age distribution, with peaks in the teens and the sixties; this reflects the age distributions of the diseases (bronchogenic carcinoma, lymphoma, pulmonary, and mediastinal metastases) that are most often evaluated by chest computed tomography. There were 199 males with a mean age of 45.1 years and 155 females with a mean age of 44.7 years.

Mean sternal size measurements are listed in Table 1. It should be noted that size measurements in Table 1 were obtained using soft tissue settings. These measurements are reported [5] to overestimate true bony size by $20-30 \%$ as compared to measurements obtained using bone windows. However, in the 10 patients in our study whose examinations were photographed at both windows, size measurements differed by less than $10 \%$. All three sternal size measurements were significantly greater in males than females, and all three correlated significantly with patient height and weight. Sternal size increased in a linear fashion up to age 25 years, after which it did not change.

Cortical thickness measurements are detailed in Table 1. For both the manubrium and the body, 


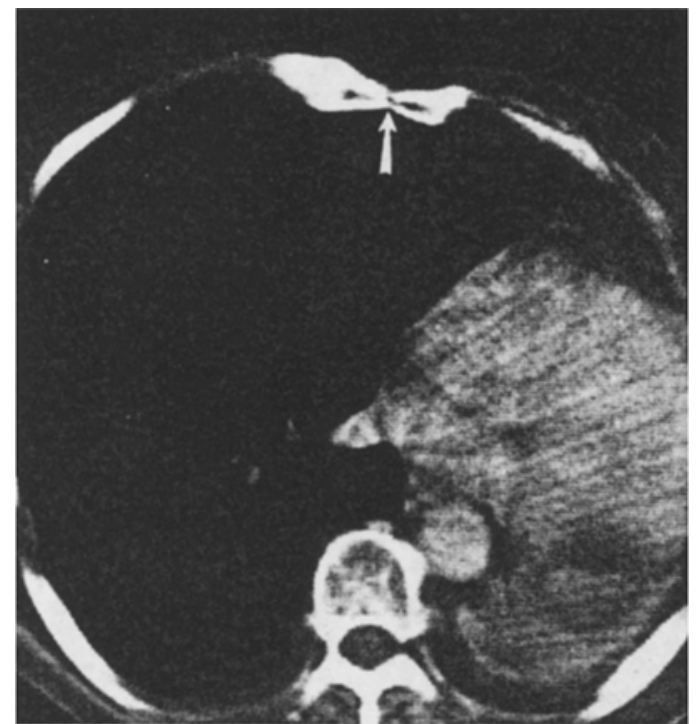

Fig. 5. Sternal foramen (arrow)

cortical thickness was significantly greater in males than females. There was also a positive correlation of cortical thickness with patient height and weight. Cortical thickness increased with age until age 20 years, after which it did not change. The medullary space of the manubrium could not be distinguished by CT using soft tissue windows in $68 \%$ of the patients under age 5 years, but this percentage gradually decreased to under $10 \%$ by age 20 years.

In all 354 patients, the manubrium and body could be distinguished on the basis of differences in size and shape (Fig. 1). The xiphoid was visible in $241 / 354(68 \%)$ patients, and was more likely to be visualized in older patients. Only 5 of 53 $(9 \%)$ patients under age 15 years had visible xiphoids, as compared to 88 of $107(82 \%)$ patients over age 30 years. The transition from manubrium to body and from body to xiphoid was often indicated by increased attenuation of bone, probably representing subarticular bone with decreased medullary space, and by slight cortical unsharpness probably reflecting the fibrocartilaginous articulations between the sternal segments (Fig. 1). In addition, the anterior aspect of the second rib, when sufficiently ossified, served as an anatomic landmark for the sternal angle.

Sternal cortical contour was sharp in 304 of $354(86 \%)$ patients. When cortical unsharpness was present, it most frequently involved the posterior aspect of the manubrium (Fig. 2) or the lateral surfaces of the body (Fig. 3). The latter is probably due to the shallow sternal notches that serve as articulations for the costal cartilage. Cortical unsharpness was seen slightly more frequently in females $(19 \%)$ than males $(11 \%)$, and was mainly found in patients over 40 years.

Sternoclavicular joint (SCJ) measurements are summarized in Table 1. This distance was significantly greater in males than females, but did not increase with patient age. Gas was noted in the $\mathrm{SCJ}$ in $29 / 344(8 \%)$ patients in whom the joint could be seen. There was no significant sex difference in the incidence of SCJ gas. SCJ gas was never seen before age 20 years, and typically occurred in patients over 40 years. SCJ bony overgrowth was noted in $48 / 344(14 \%)$ patients, and when
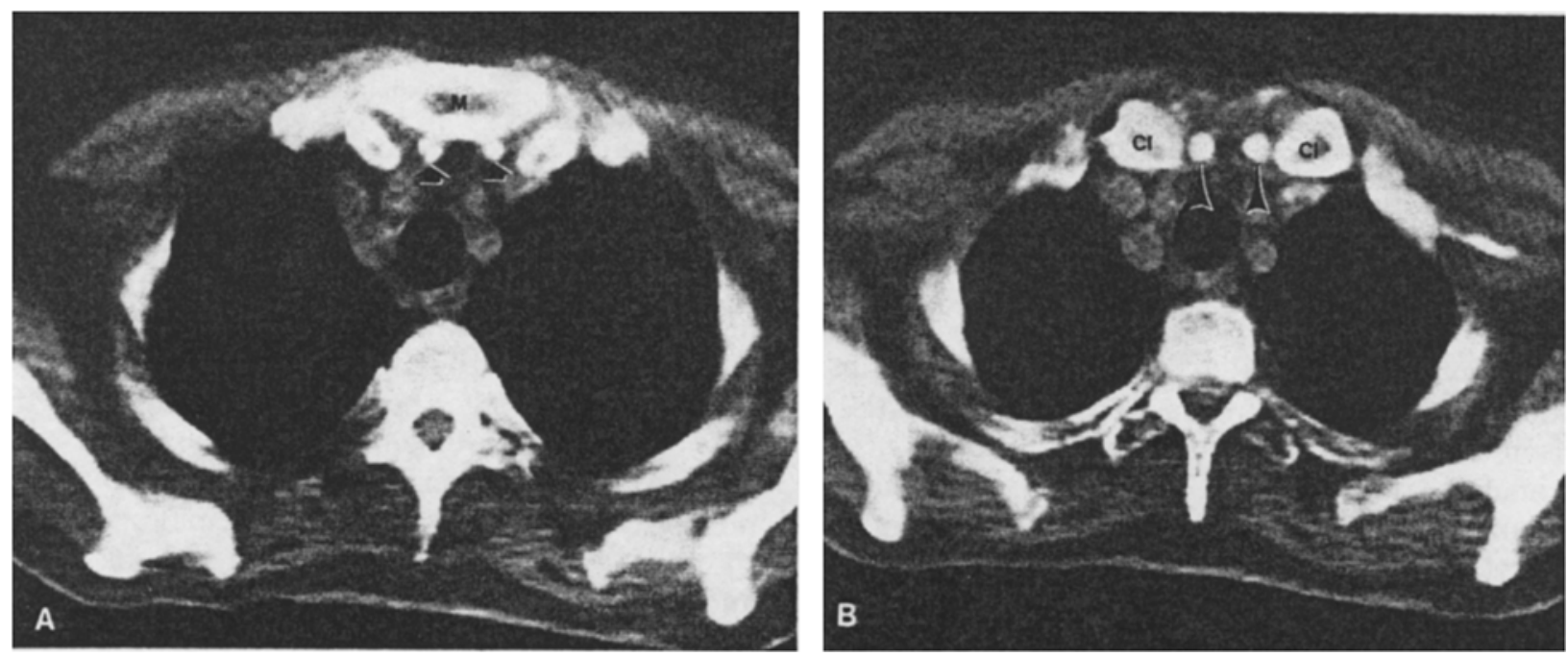

Fig. 6A, B. Suprasternal ossicles. A Paired ossicles (arrows) are found along the posterior aspect of the manubrium (M), adjacent to the sternoclavicular joints. B At a more cephalic plane of section, the ossicles (arrows) are suprasternal. $\mathrm{Cl}=$ medial ends of clavicles 
Table 3. Summary of 10 patients with suspected sternal abnormality

\begin{tabular}{|c|c|c|c|c|c|c|}
\hline $\begin{array}{l}\text { Case } \\
\text { No. }\end{array}$ & $\begin{array}{l}\text { Age } \\
\text { (years) }\end{array}$ & Sex & Chief complaint & CT findings & Final diagnosis & Mode of proof \\
\hline 1 & 66 & M & $\begin{array}{l}\text { Swelling right } 6 \text { th rib } \\
\text { anteriorly } \times 3 \text { months }\end{array}$ & $\begin{array}{l}\text { Normal sternum } \\
\text { and articulations }\end{array}$ & No evidence of neoplasm & Surgical resection \\
\hline 2 & 54 & $\mathrm{~F}$ & $\begin{array}{l}\text { Swelling left } \\
\text { clavicle }\end{array}$ & $\begin{array}{l}\text { Healing fracture of } \\
\text { medial clavicle adjacent } \\
\text { to sternoclavicular joint }\end{array}$ & No evidence of neoplasm & Surgical resection \\
\hline 3 & 53 & M & $\begin{array}{l}\text { Recurrent papillary } \\
\text { carcinoma of thyroid }\end{array}$ & $\begin{array}{l}\text { Neck mass extending down } \\
\text { into anterior mediastinum } \\
\text { and also invading sternum }\end{array}$ & $\begin{array}{l}\text { Papillary carcinoma } \\
\text { of thyroid }\end{array}$ & Surgical excision \\
\hline 4 & 75 & $F$ & Enlarging neck mass & $\begin{array}{l}\text { Neck mass extending down } \\
\text { and invading sternum }\end{array}$ & $\begin{array}{l}\text { Follicular carcinoma } \\
\text { of thyroid }\end{array}$ & Surgical resection \\
\hline 5 & 65 & M & $\begin{array}{l}\text { Known squamous cell } \\
\text { carcinoma of esophagus }\end{array}$ & $\begin{array}{l}\text { Large anterior mediastinal } \\
\text { soft tissue mass invading } \\
\text { sternum posteriorly }\end{array}$ & $\begin{array}{l}\text { Poorly differentiated } \\
\text { squamous cell carcinoma }\end{array}$ & Mediastinoscopy \\
\hline 6 & 27 & $\mathrm{~F}$ & $\begin{array}{l}\text { Pain over sternum, } \\
\text { swelling left sterno- } \\
\text { costal junction }\end{array}$ & $\begin{array}{l}\text { Large anterior mediastinal } \\
\text { soft tissue mass invading } \\
\text { sternum posteriorly }\end{array}$ & $\begin{array}{l}\text { Nodular sclerosing } \\
\text { Hodgkin disease }\end{array}$ & Chest wall biopsy \\
\hline 7 & 22 & M & Pelvic fibrosarcoma & $\begin{array}{l}\text { Soft tissue mass expanding } \\
\text { and destroying the sternum }\end{array}$ & Metastatic fibrosarcoma & $\begin{array}{l}\text { Hemipelvectomy } \\
\text { (No sternal } \\
\text { tissue obtained) }\end{array}$ \\
\hline 8 & 38 & $\mathrm{M}$ & $\begin{array}{l}\text { Pain right anterior } \\
\text { chest wall; history } \\
\text { of lateral chest wall } \\
\text { fibrosarcoma }\end{array}$ & $\begin{array}{l}\text { Parasternal soft tissue } \\
\text { mass destroying right } \\
\text { aspect of sternum } \\
\text { and adjacent rib }\end{array}$ & Metastatic fibrosarcoma & Surgical resection \\
\hline 9 & 37 & M & $\begin{array}{l}\text { Pain and swelling } \\
\text { right sternoclavicular } \\
\text { joint } \times 10 \text { months; } \\
\text { history of intravenous } \\
\text { drug abuse }\end{array}$ & $\begin{array}{l}\text { Sclerosis of the medial } \\
\text { aspect of the right clavicle } \\
\text { and the right half of the } \\
\text { manubrium with cortical } \\
\text { irregularity and adjacent } \\
\text { soft tissue mass }\end{array}$ & $\begin{array}{l}\text { Synovitis and chronic } \\
\text { osteomyelitis of the } \\
\text { sternoclavicular joint }\end{array}$ & Surgical resection \\
\hline 10 & 59 & M & $\begin{array}{l}\text { Exertional chest pain, } \\
\text { possible pulmonary } \\
\text { nodule }\end{array}$ & $\begin{array}{l}\text { Hyperostosis extending } \\
\text { posteriorly from sternum }\end{array}$ & Sternal hyperostosis & $\begin{array}{l}\mathrm{CT}, \text { follow-up } \\
\text { radiographs }\end{array}$ \\
\hline
\end{tabular}

present produced a significant decrease in the $\mathrm{SCJ}$ distance. Bony overgrowth was usually seen after age 40 years, and there was no difference in distribution between the sexes.

The density and extent of costochondral calcification are tabulated in Table 2. Males had significantly greater density and extent of costochondral calcification than females. For both sexes, density and extent of calcification increased with patient age. The soft tissue at the junction of sternum and costochondral cartilage was often quite prominent, but was generally symmetric (Fig. 4).

First rib costal cartilage calcification was present in $57.3 \%$ of patients. The presence of first rib calcification correlated significantly with the density and extent of costochondral calcification at other sites. First rib calcification was significantly more common in males ( $67 \%$ to $46 \%$ ), and was more often present in older patients.
Several normal sternal variants were encountered. These included a sternal foramen in seven patients (Fig. 5), a bifid sternum in four children under the age of 9 years, and suprasternal ossicles in three patients (Fig. 6).

\section{Abnormal Sternums}

Table 3 presents a summary of clinical, radiologic, and pathologic data for the 10 patients with clinical or radiographic evidence of sternal abnormality. Final diagnoses included direct invasion by an adjacent neoplasm in four patients (Fig. 7), metastatic neoplasm in two patients (Fig. 8), osteomyelitis in one patient (Fig. 9), and hyperostosis simulating a pulmonary nodule in one patient (Fig. 10). Two patients with clinically suspected sternal neoplasm but no CT evidence of mass underwent resection because of compelling clinical evidence on 


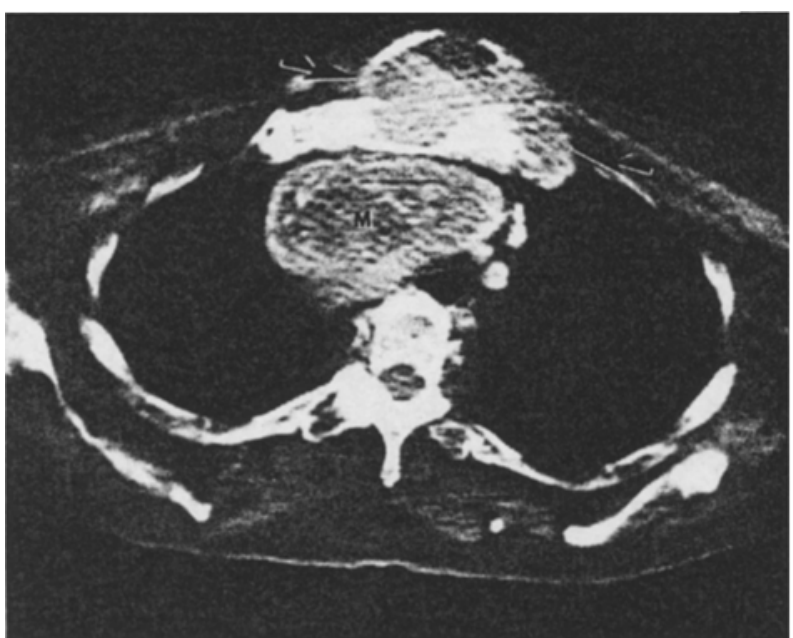

Fig. 7. Case 3. Papillary carcinoma of thyroid invading the sternum. A bilobed nonhomogeneous mass extends down into the anterior mediastinum (M) and also invades and destroys sternum (arrows)

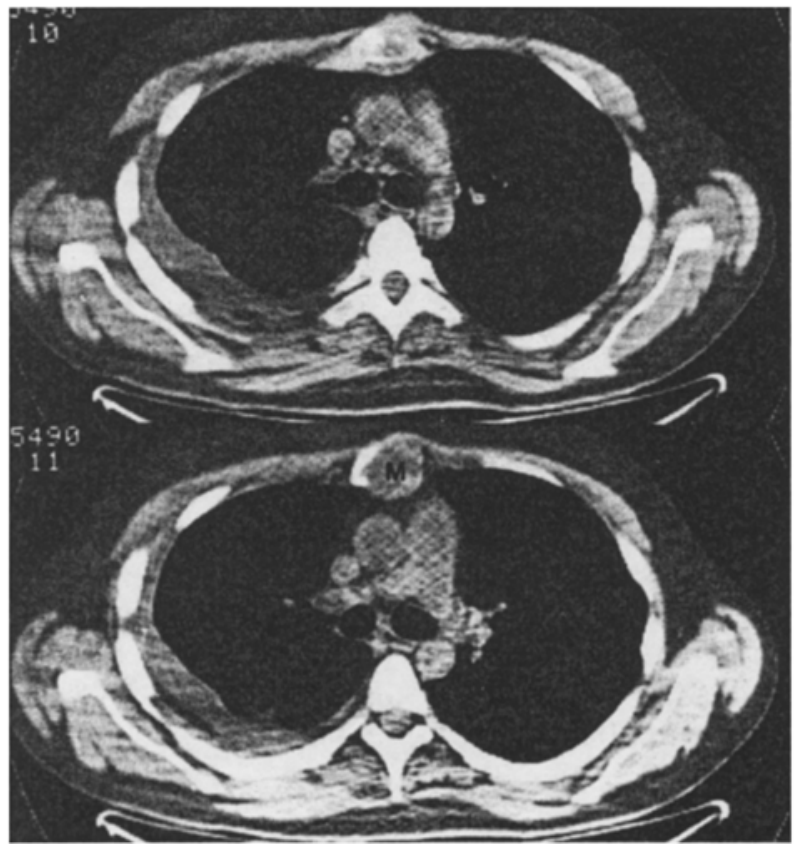

Fig. 8. Case 7. Metastatic fibrosarcoma. Adjacent scans demonstrate a soft tissue mass (M) expanding and destroying the sternum

physical examination; in each patient the final pathologic diagnosis was normal sternum (Fig. 4). Key CT features in the seven patients with clinically significant sternal abnormality included abnormal soft tissue mass $(7 / 7)$, destruction or irregularity of the cortical contour (7/7), and abnormal increased attenuation of bone (1/7) (Fig. 9).

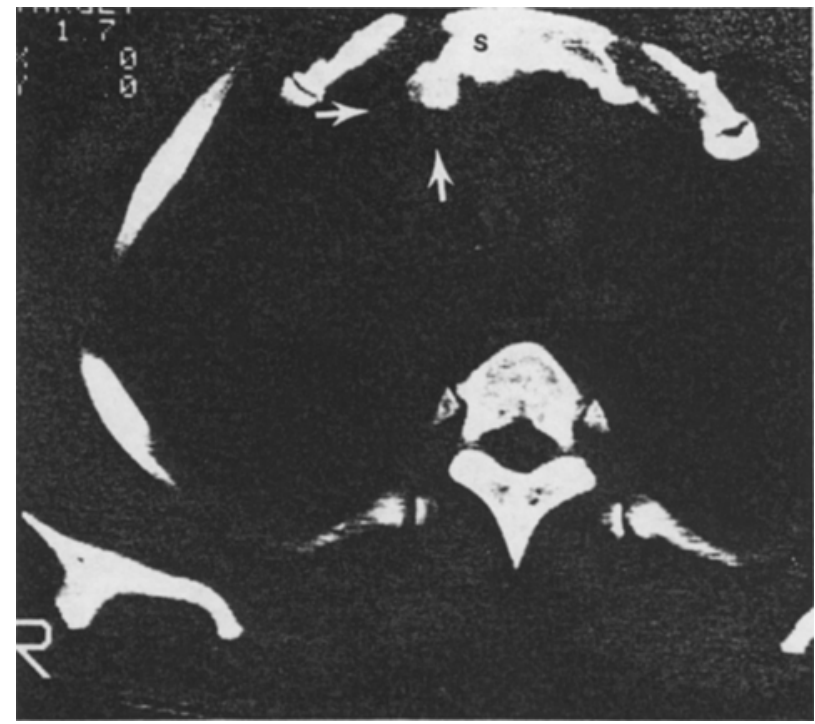

Fig. 9. Case 9. Sternal osteomyelitis. There is extensive sclerosis (S) of the right half of the manubrium with cortical irregularity and associated abnormal soft tissue (arrows). Margin of sclerosis is fairly sharp

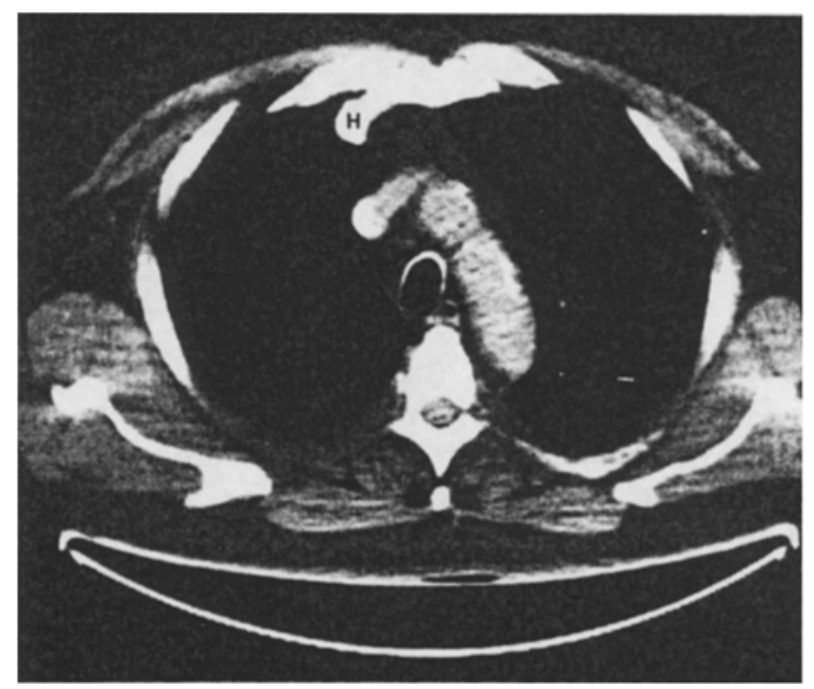

Fig. 10. Case 10. Sternal hyperostosis $(\mathrm{H})$ simulated a pulmonary parenchymal nodule on chest radiographs

\section{Discussion}

This study demonstrates that the variability of the normal sternum as visualized by CT must be appreciated for accurate diagnosis. Cortical unsharpness of the posterior manubrium, lateral body, and sternal fibrocartilaginous articulations is an impor- 


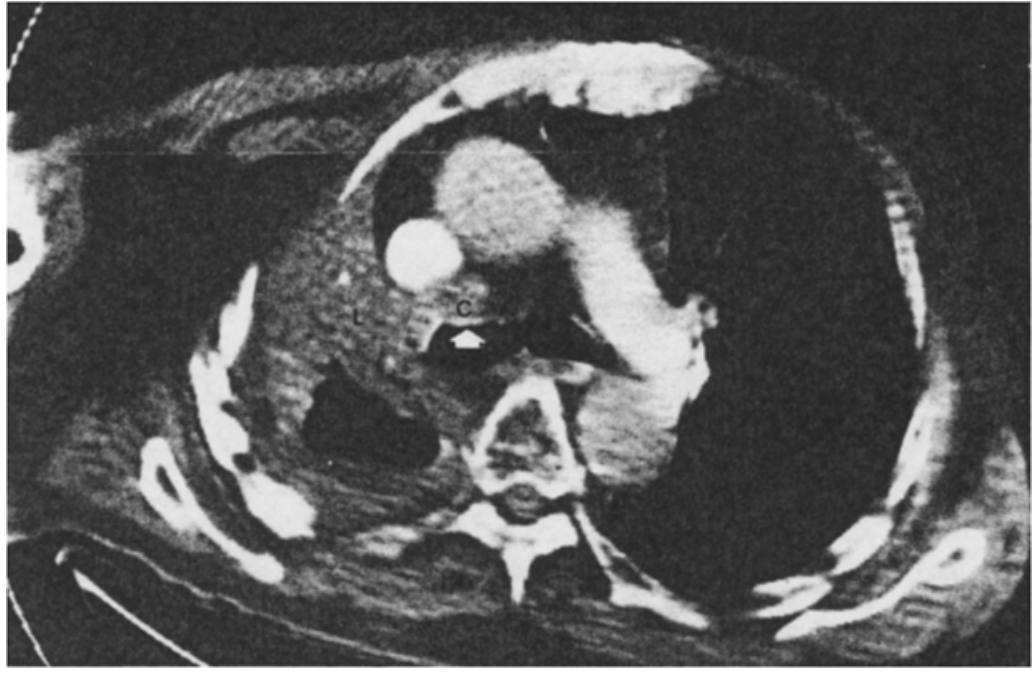

Fig. 11. Typical appearance of normal transition from body to xiphoid, with sclerosis and cortical irregularity. Compare to Figs. $4 \mathrm{~B}$ and $4 \mathrm{C}$. Note bronchogenic carcinoma $(\mathrm{C})$ indenting raight main bronchus (arrow) and resulting in right lung volume loss $(\mathrm{L})$ tant normal variant to recognize, since cortical destruction or irregularity is a typical feature of sternal abnormality. Our material suggests that destructive sternal lesions have an associated soft tissue mass, distinguishing them from normal sternums with cortical unsharpness. Another normal variant that should be recognized is the soft tissue prominence at the junction of the sternum and costochondral cartilage; this is particularly important since such prominence is palpable and may lead to unnecessary surgery, as in two of our cases. The typical location and symmetry of this prominence are reliable clues that it is a normal variant.

Bony sclerosis is a normal variant that was frequently seen at the transitions from manubrium to body and from body to xiphoid. Abnormal bony sclerosis in one patient (Fig. 9) had a more focal distribution, and was not located at a bone end. The recognition of normal bony sclerosis and cortical unsharpness at the sternal transitions (Fig. 11) facilitates accurate localization of sternal abnormalities. It also allowed us to make a correct diagnosis of normal sternum in a patient with clinically suspected sternal chondrosarcoma (Fig. 4).

In our series, CT accurately depicted various pathologic sternal conditions. Of seven patients with significant sternal abnormality, aggressive neoplasm was correctly predicted in six of six on the basis of soft tissue mass associated with cortical destruction. A benign etiology was correctly predicted in the seventh patient (sternal osteomyelitis) because of extensive sharply marginated manubrial sclerosis. CT also provided diagnostic images in a patient with sternoclavicular hyperostosis simulating a pulmonary nodule. Although we have not used CT to diagnose sternoclavicular dislocation, several previous reports have emphasized its usefulness $[2,6]$.

CT offers significant advantages in the evaluation of suspected sternal disease. Compared to plain radiography, CT provides far superior images [6]. Compared to conventional tomography, CT requires less cumulative radiation exposure [7] and generally produces superior images because of better contrast resolution and transverse tomographic display. These latter advantages permit full delineation of the location and extent of various lesions. CT should be the radiologic study of choice in patients with suspected abnormality of the sternum and its articulations.

\section{References}

1. deGautard R, Dussault RG, Chahlaoui J, Duranceau A, Sylvestre $\mathrm{J}$ (1981) Contribution of CT in thoracic bony lesions. J Can Assoc Radiol 32:39

2. Destouet JM, Gilula LA, Murphy WA, Sagel SS (1981) Computed tomography of the sternoclavicular joint and sternum. Radiology 138:123

3. Goodman LR, Teplick SK, Kay H (1983) Computed tomography of the normal sternum. AJR 141:219

4. Gouliamos AD, Carter BL, Emami B (1980) Computed tomography of the chest wall. Radiology $134: 433$

5. Koehler PR, Anderson RE, Baxter B (1979) The effect of computed tomography viewer controls on anatomical measurements. Radiology 130:189

6. Levinsohn EM, Bunnell WP, Yuan HA (1979) Computed tomography in the diagnosis of dislocations of the sternoclavicular joint. Clin Orthop 140:12

7. Maue-Dickson W, Trefler M, Dickson DR (1979) Comparison of dosimetry and image quality in computed and conventional tomography. Radiology 131:509

8. Rozboril MB, Good AE, Zarbo RJ, Schultz DA (1983) Sterno-clavicular joint arthritis: An unusual manifestation of metastatic carcinoma. J Rheumatol 10:499 